\title{
THE (A)SYMMETRY OF THE MALE GRAYING BEARD HAIRS AS AN INDICATION OF THE PROGRAMMED AGING PROCESS
}

\author{
Borut Poljsak ${ }^{1}$, Raja Dahmane ${ }^{2}$, Metka Adamič ${ }^{3}$, Robert Sotler ${ }^{1}$,Tina Levec ${ }^{1}$, \\ Doroteja Pavan Jukić ${ }^{4}$, Cecilija Rotim ${ }^{5}$, Tomislav Jukić ${ }^{6}$ and Andrej Starc ${ }^{1}$ \\ ${ }^{1}$ Laboratory for Oxidative Stress Research, Faculty of Health Sciences, University of Ljubljana, Ljubljana, Slovenia; \\ ${ }^{2}$ Department of Biomedicine in Health Care Division, Faculty of Health Sciences, Faculty of Medicine, \\ Institute of Anatomy, University of Ljubljana, Ljubljana, Slovenia; \\ ${ }^{3}$ Metka Adamič Dermatology Clinic, Ljubljana, Slovenia; \\ ${ }^{4}$ Josip Juraj Strossmayer University of Osijek, Faculty of Medicine, \\ Department of Gynecology and Obstetrics, Osijek, Croatia; \\ ${ }^{5}$ Dr Andrija Štampar Teaching Institute of Public Health, Zagreb, Croatia; \\ ${ }^{6}$ Josip Juraj Strossmayer University of Osijek, Faculty of Medicine, Department of Internal Medicine, \\ Family Medicine and History of Medicine, Osijek, Croatia
}

SUMMARY - Aging interventions will be ineffective if we do not understand the basic principles of aging. Currently, there is no consensus on the issue whether aging is programmed or not. The hypothesis presented in this article indicates that aging (at least graying of male hairs) is programmed. This hypothesis is supported by the symmetry of the graying of male beard hairs. According to stochastic theories of aging, aging is a passive non-programmed process where random dispersion of graying hairs should result. On the contrary, programmed theories of aging would predict that there should be symmetry on the left and right parts of the face showing the same proportion, pattern and time of appearance of graying hairs.

Key words: Graying beard hair; Graying hair; Aging; Programmed theory of aging; Stochastic theory of aging

\section{Introduction}

What triggers the aging process? Why do living beings age? Could this process be slowed down or even reversed? Is aging programmed, is it under genetic control or not? Although significant advances in biochemical and medical science have been made in the last 50 years, answers to these questions remain a matter of debate among different aging theorists ${ }^{1-3}$.

Correspondence to: Assist. Prof. Andrej Starc, PhD, Laboratory for Oxidative Stress Research, Department of Public Health, Faculty of Health Sciences, University of Ljubljana, Zdravstvena pot 5, 1000 Ljubljana, Slovenia

E-mail: andrej.starc@guest.arnes.si

Received September 18, 2018, accepted October 22, 2018
Several theories aimed to specify and define the aging process, each from a different perspective, but none was able to explain the whole complexity of senescence. Traditional theories of aging oppose that aging is genetically programmed, or that it is the result of adaptation. In general, theories that explain aging have been classified into the programmed (or deterministic) and stochastic (random; damage/error) ones. The two main (and subdivided) categories of aging as explained by modern biological theories are: (a) programmed: (1) programmed longevity, (2) endocrine theory, (3) immunological theory, (4) theory of phenoptosis, (5) nutrient sensing theory, (6) theory of biological clocks (epigenetic theory) and (7) demographic theory of aging $^{4}$; and (b) damage or error theories: (1) wear and 
tear theory, (2) rate of living theory, (3) cross-linking theory, (4) free radical theory and (5) somatic DNA damage theory ${ }^{5}$.

Stochastic models explain aging process as a result of progressive accumulation of random molecular damage and see aging as an entirely passive process ${ }^{4,6}$. According to the most popular stochastic wear and tear theory of aging, first propounded by August Weismann in 1882, the effects of aging are caused by progressive damage to cells and body systems over time. The consequences of aging are thus attributed to gradual damage to cells and body systems over time, indicating that deterioration is random and is not under active control by the genes or any other biological 'program'. Programmed theories, however, suggest that aging is genetically encoded and regulated by genes or other biological clocks operating throughout the lifes$\mathrm{pan}^{5}$. Aging thus follows a biological timetable which is programmed or regulated by changes in gene expression and/or deterioration of several disease s $^{1,5,7-9}$.

\section{Evidence indicating that aging is under a genetic program}

Some gerontology researchers and evolutionary biologists try to explain aging as being programmed, although this view is advocated only by the minority of aging researchers ${ }^{1,9-21}$.

There are several examples suggesting that aging might be programmed, for example, model organisms, being able to increase longevity under different stressful life circumstances due to the phenomena of horme$\operatorname{sis}^{22-25}$. Other studies later confirmed the association between telomere shortening and longevity ${ }^{26-32}$. Shortening of telomeres contributes to aging by the following two mechanisms ${ }^{33}$ : if telomeres are too short in stem cell tissue, the cells cannot be regenerated, and cells with short telomeres are the cause of increased inflammation ${ }^{34}$. However, some animal species suffer deterioration with age although their telomeres do not become shorter with advanced age and human neurons suffer aging although being post-mitotic. Aging could be explained as a process of adaptation to endogenous and/or exogenous factors, as a population turnover, evolution, prevention of demographic influences, and to stabilize the population ${ }^{20,35-38}$.

Recent studies focus attention on telomere shortening as a strong prognosticator of age-adjusted death rate ${ }^{26,27,30,32,39,40}$. Recently, highlights have been orient- ed also towards thymus involution. During the evolution of the body, the thymus gland becomes smaller and loses functionality. This effect causes several errors in non-detection of microbes and/or tissues attacked and/or autoimmune response, etc. ${ }^{33}$. However, not every organ is unified with the modes of aging. During the neuronal growth, the brain is not limited by the influence of telomere or by the thymus, but by the epigenetic programming ${ }^{41,42}$. Several authors suggested the existence of epigenetic aging clock $^{43,44}$. Even Leonard Hayflick's discovery of limited replicative capability indicates that cells are programmed to die (or enter senescence $)^{45,46}$. If aging is programmed, what is the master clock regulating it? Up to now, no such clock has been discovered, but many possibilities have been proposed, e.g., thymic involution, the suprachiasmatic nucleus, telomere shortening, the hypothalamus, and replicative senescence ${ }^{47}$.

\section{Graying of the hair}

The hair follicle pigmentary unit is also strongly responsive to changes associated with age. The precise mechanisms which account for the decrease of melanogenically active melanocytes from anagen adult hair follicles with aging, are still unsubstantiated. Gray hair follicles have noticeably lowered the number of differentiated and functioning melanocytes found in the hair bulb. On the other hand, hair follicles known as 'senile white' follicles may have no melanocytes in the hair bulb region of the hair follicle ${ }^{48}$. It has been established that the loss of hair shaft melanin is related to reduction of the bulb melanin content, as well as of the bulb melanocyte population. Hair graying is presumably an aftermath of the entire and specific emptying of the bulb and in the outer root sheath melanocytes of human hair ${ }^{49}$. When the reservoir of stem cells is depleted, the production of pigment ceases and the hairs turn gray. Does the hair follicle have a 'melanogenetic clock', which decelerates or ceases melanocyte activity, resulting in graying of the hair?

\section{Hypothesis}

If graying of the beard is not programmed, then a random distribution of gray (hairs) parts should be observed (Fig. 1b). On the other hand, if graying is programmed, the symmetrical areas on the left and on the right side of the face should appear, as presented in Figure 1a. 

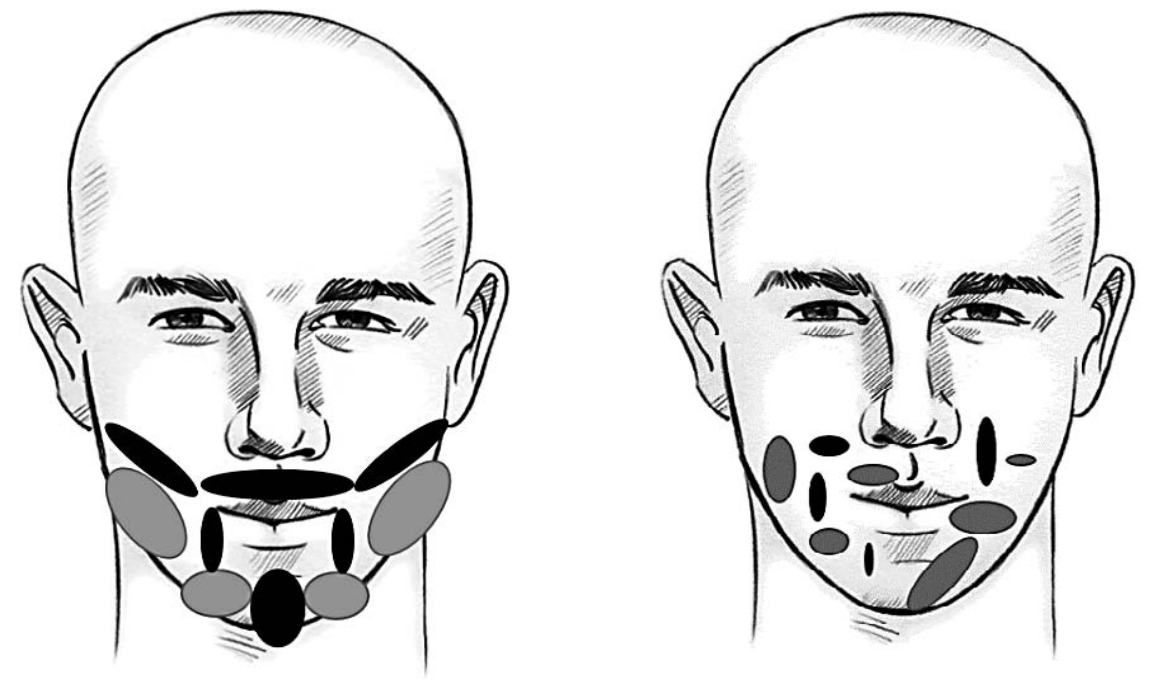

Fig. 1. Symmetrical pattern of graying zones of the face (a) and random pattern of graying zones of the face (b).

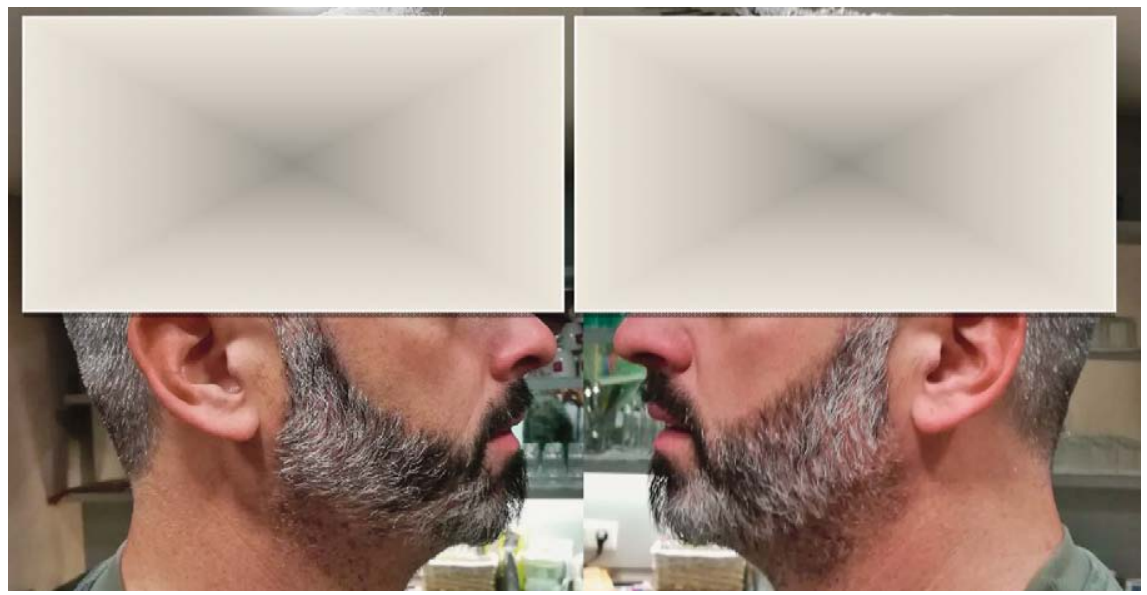

Fig. 2. Picture of a male, 38 years, with graying beard.

Picture shows a symmetrical pattern of graying area, taken from the right and left parts of the face.

\section{Methods}

Two different commercially available programs (Facial Symmetry and PicHacks-The Symmetrical Face Generator) were applied for preparation of face mirror pictures. Fifteen pictures of male adults with different degree of gray beard areas were chosen and facial symmetry/mirror pics were prepared. Pictures in Figures 2 and 3 were taken with a color 16-megapixel camera, showing frontal and two lateral face pictures of a 38-year-old male adult, who gave a written con- sent for participation. Pictures in Figures 4-14 were downloaded from publicly accessible web pages and belong to known celebrity persons.

\section{Results}

The pictures in Figure 2 indicate a symmetrical distribution pattern of graying hairs, as it can be observed when a mirror picture of the left and the right side of the face is composed with a computer program. 


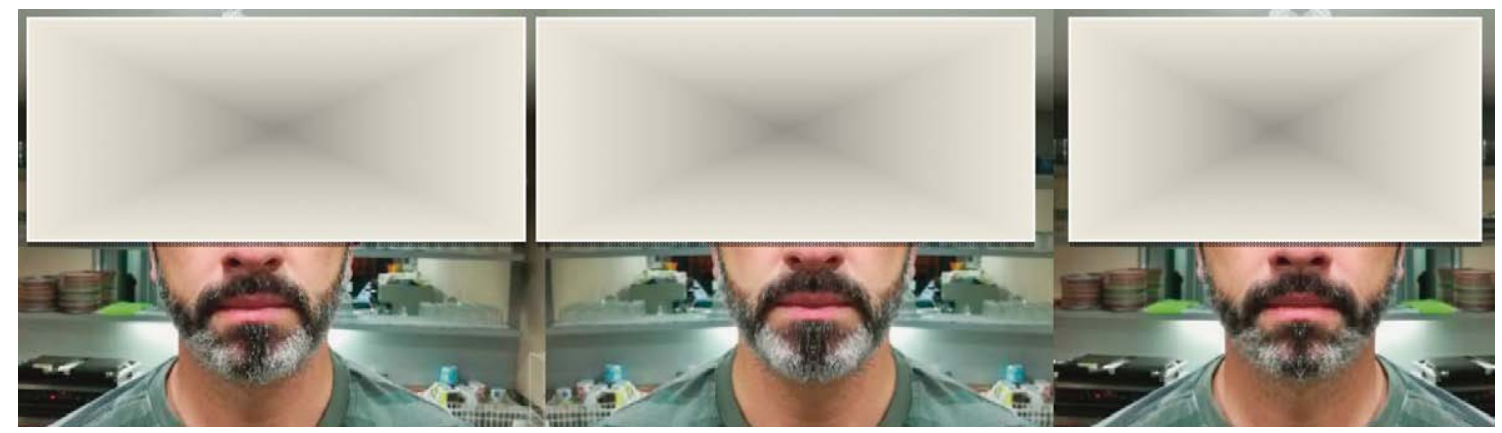

Fig. 3. Original face picture $(A)$ and simulation of the symmetry of the left $(B)$ and right $(C)$ side of the face with a computer program using two computer programs, Facial Symmetry and PicHacks-The Symmetrical Face Generator.

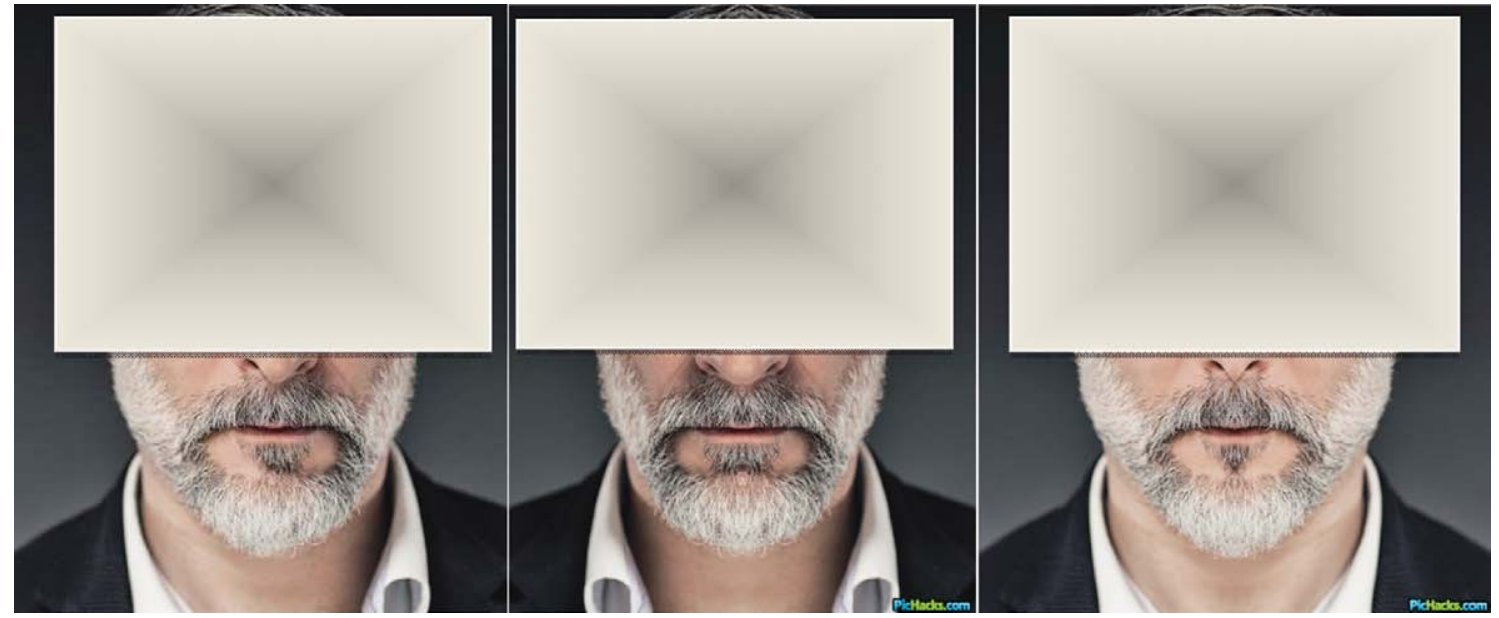

Fig. 4. Original face picture $(A)$ and simulation of the symmetry of the left $(B)$ and right side $(C)$ of the face with the PicHacks-The Symmetrical Face Generator computer program.
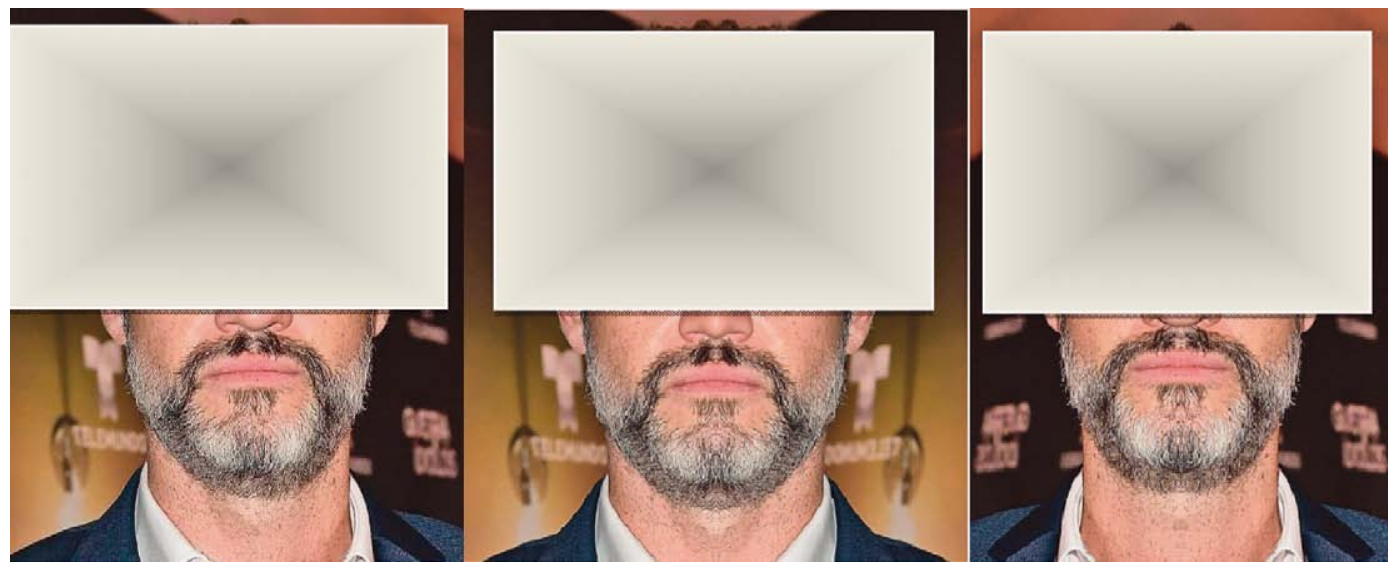

Fig. 5. Original face picture $(A)$ and simulation of the symmetry of the left $(B)$ and right side $(C)$ of the face with the PicHacks-The Symmetrical Face Generator computer program. 


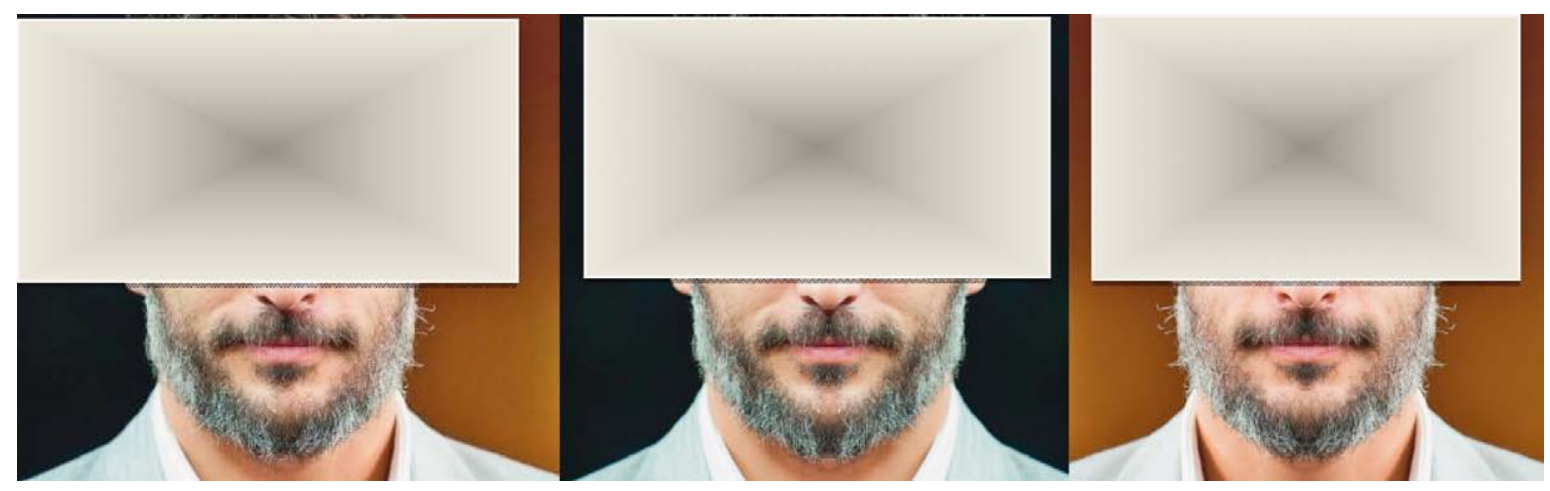

Fig. 6. Original face picture $(A)$ and simulation of the symmetry of the left $(B)$ and right side $(C)$ of the face with the PicHacks-The Symmetrical Face Generator computer program.

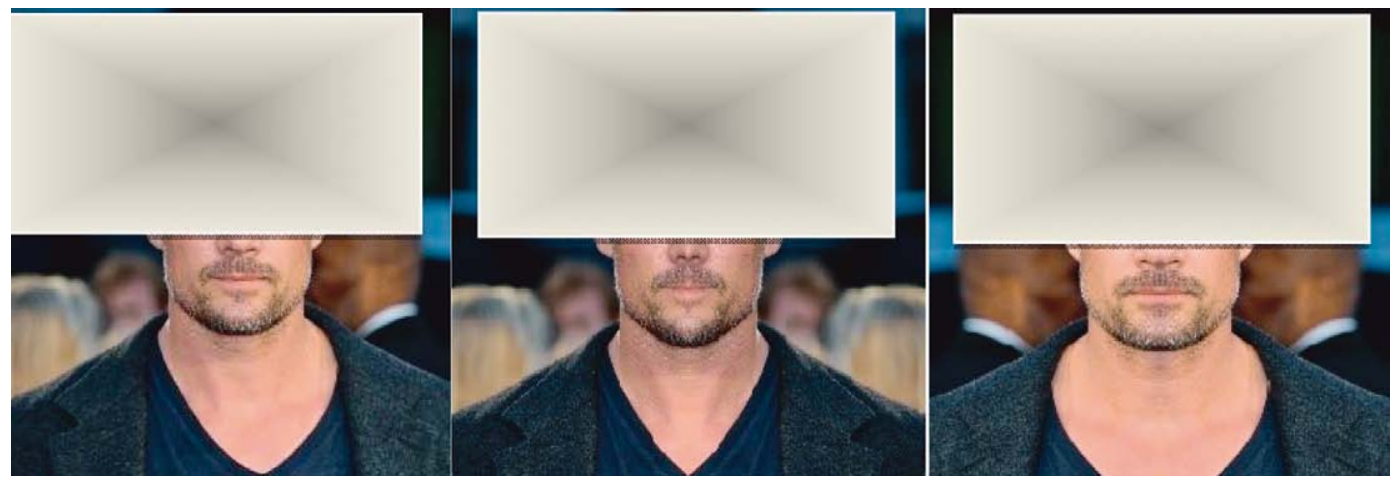

Fig. 7. Original face picture $(A)$ and simulation of the symmetry of the left $(B)$ and right side $(C)$ of the face with the PicHacks-The Symmetrical Face Generator computer program.
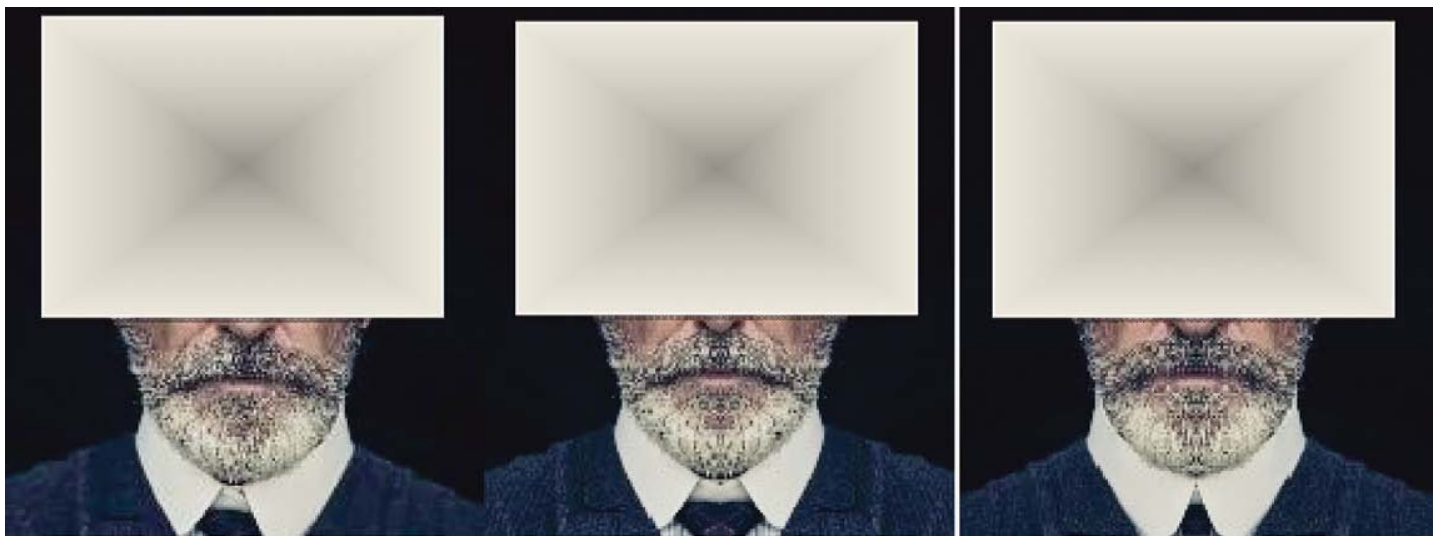

Fig. 8. Original face picture $(A)$ and simulation of the symmetry of the left $(B)$ and right side $(C)$ of the face with the PicHacks-The Symmetrical Face Generator computer program.

Figures 3-13 indicate a symmetrical distribution pattern of graying hairs, as it can be observed when a mirror picture of the left (B) and the right part (C) of the face is composed with a computer program.

\section{Discussion}

The aging process is similar in all humans and other living organisms. If mutations in the nuclear and mitochondrial DNA, cellular proteins and lipids ac- 


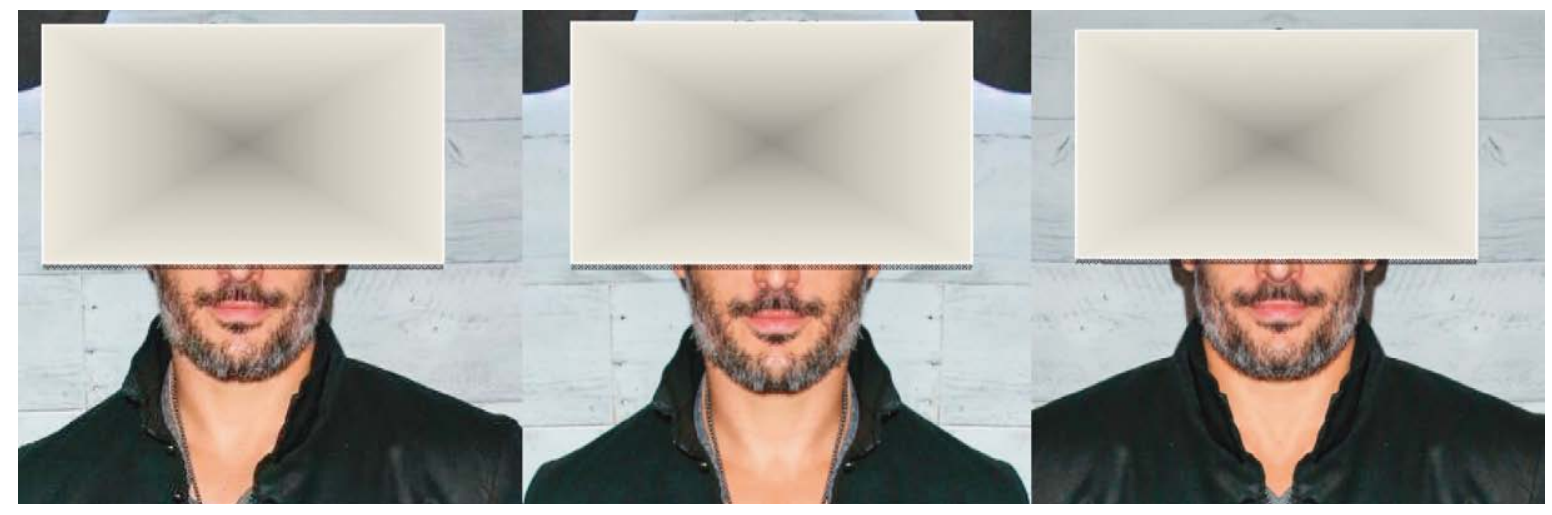

Fig. 9. Original face picture $(A)$ and simulation of the symmetry of the left $(B)$ and right side $(C)$ of the face with the PicHacks-The Symmetrical Face Generator computer program.

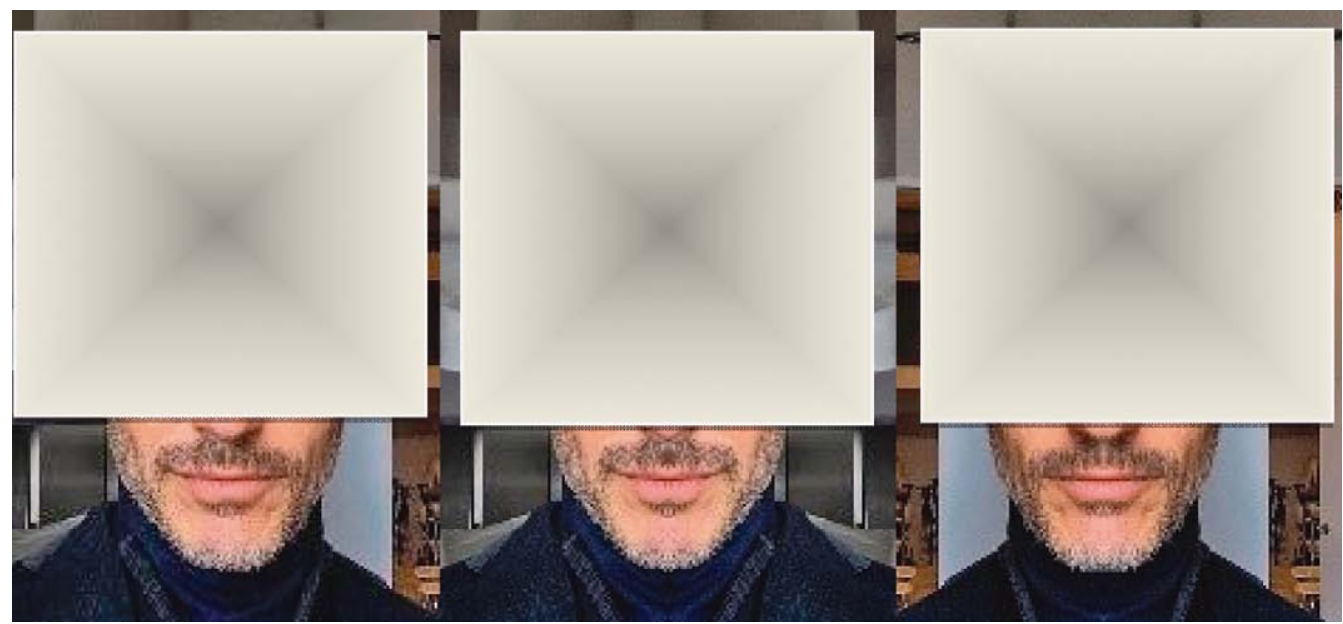

Fig. 10. Original face picture $(A)$ and simulation of the symmetry of the left $(B)$ and right side (C) of the face with the PicHacks-The Symmetrical Face Generator computer program.

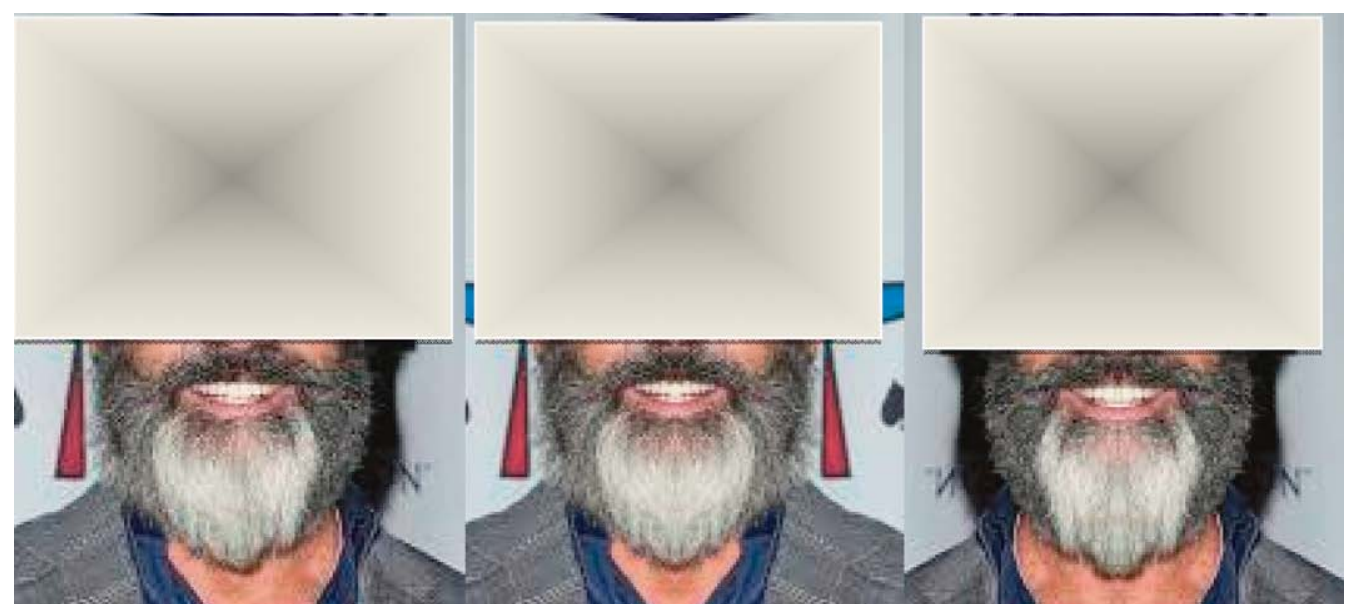

Fig. 11. Original face picture (A) and simulation of the symmetry of the left (B) and right side (C) of the face with the PicHacks-The Symmetrical Face Generator computer program. 


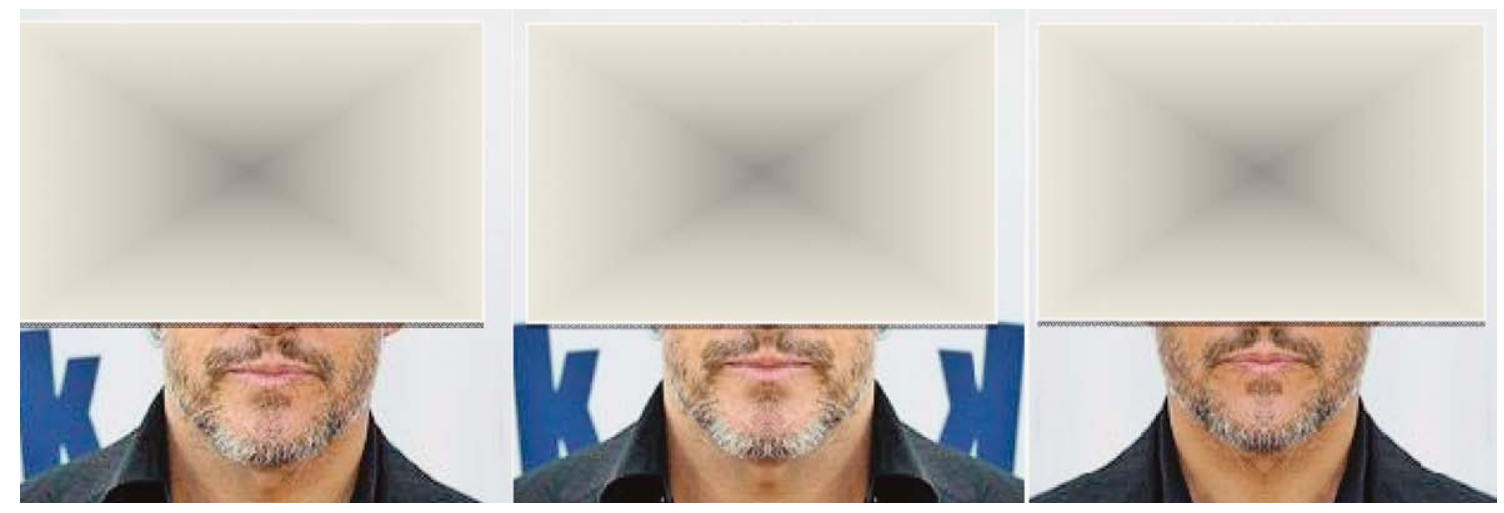

Fig. 12. Original face picture $(A)$ and simulation of the symmetry of the left $(B)$ and right side $(C)$ of the face with the PicHacks-The Symmetrical Face Generator computer program.

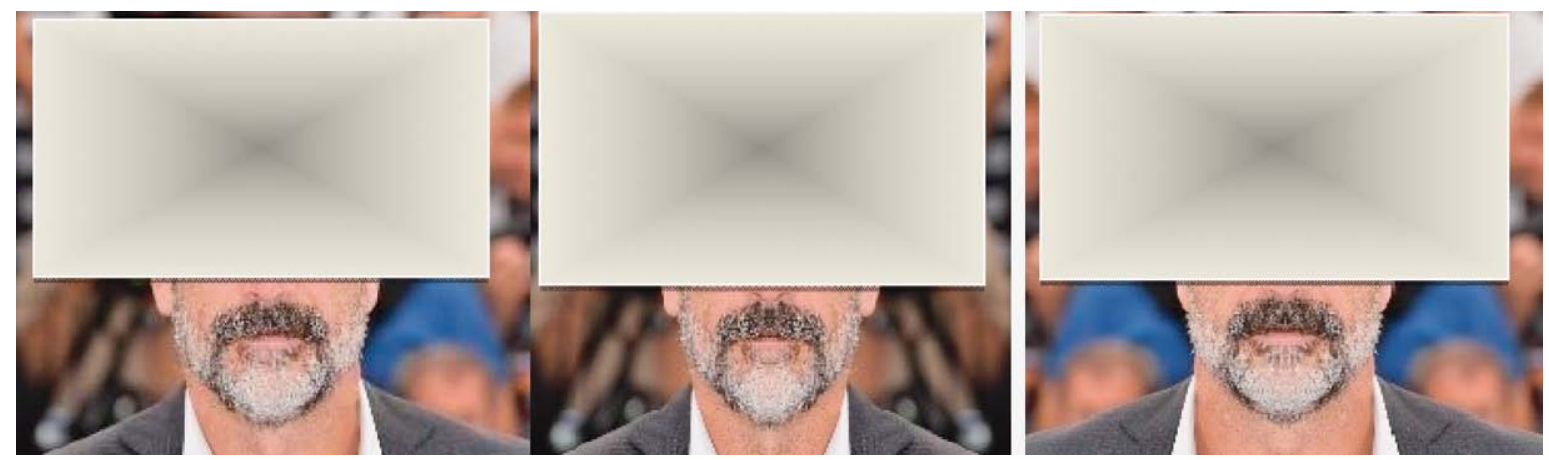

Fig. 13. Original face picture $(A)$ and simulation of the symmetry of the left $(B)$ and right side $(C)$ of the face with the PicHacks-The Symmetrical Face Generator computer program.

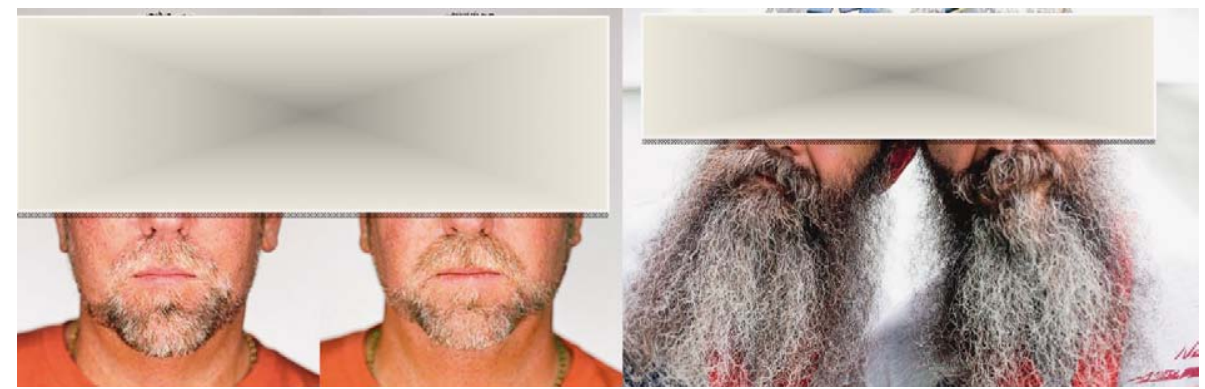

Fig. 14. Identical twins becoming gray at approximately the same age, rate and pattern.

cumulate randomly as we age, we should then age in many different rates and ways as we do. Methylation, histone alterations, inflammation and other causes of DNA alteration would result in random modification of epigenome and in nonsymmetrical variation of the random graying patterns.

Additionally, there are syndromes which can accelerate aging. Early graying can be observed in prema- ture aging syndromes, e.g., Hutchinson progeria and Werner syndrome, where aging process is intensified. Premature graying can also be experienced by people suffering from pernicious anemia, autoimmune thyroid disease or Down syndrome ${ }^{50-52}$.

Conceding that the genes control exhaustion of the pigmentary potential of every hair follicle, this phenomenon will thus occur synchronously in individual 
hair follicles and the pattern of graying hair should be symmetrical on both sides of the face. The results presented with aging of the hair follicles of the male beard indicate a symmetrical pattern of the graying parts on the left and right sides, as can be observed in Figures $2-13$. These findings suggest that graying areas are not formed as random distribution.

Genetic factors seem to be decisive in hair greying, as identical twins apparently become grey at approximately the same age, rate and pattern (Fig. 14). The controlling program/clock/, however, has not yet been identified. Even though several aging genes have been discovered, the interferon regulatory factor (IRF4) and B-cell lymphoma 2 have been identified to have a significant impact on hair graying. It has recently been discovered that IRF4 gene may play a significant role in hair graying. The IRF4 gene, when expressed, is important in melanin production, which governs hair pigmentation ${ }^{53,54}$. Wood et al..$^{55}$ have ascertained that hair follicles develop small quantities of hydrogen peroxide. This reactive species builds on the hair shafts, potentially leading to a progressive loss of hair color. Free radical theory of aging additionally supports the theory of programmed aging. Reactive oxygen species contribute to the accumulation of oxidative damage to the hair follicle stem cell niche, which leads to selective apoptosis and diminution of melanocyte stem cells, reducing repopulation of the newly formed anagen follicles ${ }^{56,57}$.

By manipulation of a single gene or by affecting signaling pathways with a single molecule, longevity could be significantly extended. Different mutations in various organisms, from microorganisms to mice, can extend life expectancy. For example, a mutation in the age-1 gene of the nematode Caenorhabditis elegans significantly prolongs both the maximum and the average lifespan ${ }^{58,59}$. Functioning of the SERPINE1 gene that encodes PAI-1 to be mutated and non-functional has also been recently reported in humans, i.e. in Berne Amish families with prolonged life $\operatorname{span}^{60}$. In all species including mammals, mutations that deactivate specific signaling pathways (e.g., insulin/IGF-1, mTOR, AMPK signaling) impede the aging process and promote longevity ${ }^{61-67}$. These mutations display evolutionarily preserved pathways for aging, some of which supposedly enhance longevity as a reaction to sensory cues, caloric restriction, or stress ${ }^{68}$.
By comparison, the symptoms of human senescence are unvarying, and include skin wrinkles and male baldness, insulin-resistance and osteoporosis, high blood pressure and atherosclerosis, obesity and diabetes, cancer and Alzheimer's disease ${ }^{68}$. What is more, in certain species (e.g., Pacific salmon), all members die at the same specific time and from the same cause, which indicates that many aspects of the aging process are programmed.

\section{Limitations of the study}

The main limitation of the present study was a small sample consisting of only 12 bearded persons. Another limitation was that only indirect correlation between graying of the beard parts and programmed aging was presented, which does not necessarily reflect the causal link between them. Further biochemical and genetic research is needed to confirm the causality.

\section{Conclusions}

Many of the presented aging theories correlate in a complex manner. In order to promote successful aging and to enhance the lifespan of the humankind, it is necessary to delve into and to test the recognized and emerging aging theories. It seems that aging is controlled also by our genes, as indicated in the references presented and, as in our case, by the graying patterns of the hairs. On the other hand, it should be emphasized that aging can be modulated to a certain degree by diet and healthy lifestyle.

\section{References}

1. Kirkwood TB, Melov S. On the programmed/non-programmed nature of ageing within the life history. Curr Biol. 2011 Sep 27;21(18):R701-7. doi: 10.1016/j.cub.2011.07.020. PMID: 21959160.

2. Skulachev VP. Ageing as a particular case of phenoptosis, the programmed death of an organism (a response to Kirkwood and Melov: On the programmed/non-programmed nature of ageing within the life history). Ageing (Albany NY). 2011 Nov;3(11):1120-3. doi: 10.18632/aging. 100403.

3. Skulachev VP. What is "phenoptosis" and how to fight it? Biochemistry (Mosc). 2012 Jul;77(7):689-706. doi: 10.1134/ S0006297912070012.

4. Chmielewski P. Rethinking modern theories of ageing and their classification: the proximate mechanisms and the ultimate 
explanations. Anthropol Rev. 2017;80(3):259-72. doi: https:// doi.org/10.1515/anre-2017-0021

5. Jin K. Modern biological theories of ageing. Ageing Dis. 2010 Oct 1;1(2):72-4. PMID: 21132086; PMCID: PMC2995895.

6. Kirkwood TB. Understanding the odd science of ageing. Cell. 2005 Feb 25;120(4):437-47. doi: 10.1016/j.cell.2005.01.027. PMID: 15734677.

7. Bašić Kes V, Jurašić MJ, Zavoreo I, Lisak M, Jeleč V, Zadro Matovina L. Age and gender differences in acute stroke hospital patients. Acta Clin Croat. 2016;55:69-78, doi: 10.20471/ acc.2016.55.01.11.

8. Prskalo K, Klarić Sever E, Alerić I, Antonić Jelić T, Žaja I. Risk factors associated with black tooth stain. Acta Clin Croat. 2017;56:28-35, doi: 10.20471/acc.2017.56.01.05

9. Gavrilova N, Gavrilov LA, Severin FF, Skulachev VP. Testing predictions of the programmed and stochastic theories of ageing: comparison of variation in age at death, menopause, and sexual maturation. Biochem (Mosc). 2012;77(7):754-60. doi: 10.1134/S0006297912070085.

10. Bowles JT. The evolution of ageing: a new approach to an old problem of biology. Med Hypotheses. 1998;51(3):179-221. doi: 10.1016/s0306-9877(98)90079-2.

11. Skulachev VP. Phenoptosis: programmed death of an organism. Biochem (Mosc). 1999; 64(12):1418-26. PMID: 10648966.

12. Skulachev VP. Programmed death phenomena: from organelle to organism. Ann N Y Acad Sci. 2002;959:214-37. doi: 10.1111/j.1749-6632.2002.tb02095.x.

13. Goldsmith TC. Arguments against non-programmed ageing theories. Biochem (Mosc) 2013;78(9):971-8. doi: 10.1134/ S0006297913090022. PMID: 24228918.

14. Fabrizio P, Battistella L, Vardavas R, et al. Superoxide is a mediator of an altruistic ageing program in Saccharomyces cerevisiae. J Cell Biol. 2004;166(7):1055-67. doi: 10.1083/jcb.2004 04002.

15. Mitteldorf J. Ageing selected for its own sake. Evol Ecol Res. 2004;6:1-17.

16. Bredesen DE. The non-existent ageing program: how does it work? Ageing Cell. 2004;3(5):255-9. doi: 10.1111/j.14749728.2004.00121.x.

17. Travis JM. The evolution of programmed death in a spatially structured population. J Gerontol A Biol Sci Med Sci. 2004;59(4):301-5. doi: 10.1093/gerona/59.4.b301.

18. Longo VD, Mitteldorf J, Skulachev VP. Programmed and altruistic ageing. Nat Rev Genet. 2005;6(11):866-72. doi: 10.1038/nrg1706.

19. Mitteldorf J. Evolutionary origins of ageing. In: Fahy GM, et al. (eds). Approaches to the Control of Ageing: Building a Pathway to Human Life Extension. New York: Springer, 2010; pp. 87-126.

20. Martins AC. Change and ageing senescence as an adaptation. PLoS One. 2011;6(9):e24328. doi: 10.1371/journal.pone. 0024328 .
21. Skulachev MV, Skulachev VP. New data on programmed ageing - slow phenoptosis. Biochem (Mosc). 2014;79(10):977-93. doi: 10.1134/S0006297914100010.

22. Calabrese EJ, Baldwin LA. Hormesis as a biological hypothesis. Environ Health Perspect. 1998;106(Supp 1):357-62. doi: 10.1289/ehp.98106s1357.

23. Calabrese EJ. Toxicological awakenings: the rebirth of hormesis as a central pillar of toxicology. Toxicol Appl Pharmacol. 2005;204(1):1-8. doi: 10.1016/j.taap.2004.11.015.

24. Masoro EJ. Overview of caloric restriction and ageing. Mech Ageing Dev. 2005;126(9):913-22. doi: 10.1016/j.mad.2005. 03.012.

25. Masoro EJ. The role of hormesis in life extension by dietary restriction. Interdiscip Top Gerontol. 2007;35:1-17. doi: 10.1159/000096552

26. Bischoff C, Graakjaer J, Petersen HC, Jeune B, Bohr VA, Koelvraa S, Christensen K. Telomere length among the elderly and oldest-old. Twin Res Hum Genet 2005;8(5):425-32. doi: 10.1375/183242705774310079.

27. Harris SE, Deary IJ, Maclntyre A, Lamb KJ, Radhakrishnan K, Starr JM, Whalley LJ, Shiels PG. The association between telomere length, physical health, cognitive ageing, and mortality in non-demented older people. Neurosci Lett. 2006;406(3):2604. doi: 10.1016/j.neulet.2006.07.055.

28. Brouilette SW, Moore JS, McMahon AD, Thompson JR, Ford I, Shepherd J, Packard CJ, Samani NJ. Telomere length, risk of coronary heart disease, and statin treatment in the West of Scotland Primary Prevention Study: a nested case-control study. Lancet. 2007;369(9556):107-14. doi: 10.1016/S01406736(07)60071-3.

29. Kimura M, Hjelmborg, JVB, Hjelmborg JVB, Gardner JP, Bathum L, Brimacombe M, Lu X, Christiansen L, Vaupel JW, Aviv A, Christensen K. Telomere length and mortality: a study of leukocytes in elderly Danish twins. Am J Epidemiol. 2008;167(7):799-806. doi: 10.1093/aje/kwm380.

30. Strandberg TE, Saijonmaa O, Tilvis RS, Pitkala KH, Strandberg AY, Miettinen TA, Fyhrquist F. Association of telomere length in older men with mortality and midlife body mass index and smoking. J Gerontol A Biol Sci Med Sci. 2011;66(7):815-20. doi: 10.1093/gerona/glr064.

31. Ma H, Zhou Z, Wei S, Liu Z, Pooley KA, Dunning AM, Svenson U, Roos G, Hosgood HD III, Shen M, Wei Q. Shortened telomere length is associated with increased risk of cancer: a meta-analysis. PLOS One. 2011;6(6):e20466. doi: 10.1371/ journal.pone.0020466.

32. Willeit P, Willeit J, Kloss-Brandstatter A, Kronenberg F, Kiechl S. Fifteen-year follow-up of association between telomere length and incident cancer and cancer mortality. JAMA. 2011;306(1):42-4. doi: 10.1001/jama.2011.901.

33. Mitteldorf J. Ageing Is a Group-Selected Adaptation: Theory, Evidence, and Medical Implications. Boca Raton: CRC Press, 2016.

34. Baker DJ, Wijshake T, Tchkonia T, LeBrasseur NK, Childs BG, van de Sluis B, Kirkland JL, van Deursen JM. Clearance 
of p16Ink4a-positive senescent cells delays ageing-associated disorders. Nature. 2011;479(7372):232-6. doi: 10.1038/nature10600.

35. Mitteldorf J, Pepper J. Senescence as an adaptation to limit the spread of disease. J Theor Biol. 2009;260(2):186-95. doi: 10.1016/j.jtbi.2009.05.013.

36. Mitteldorf J, Goodnight C. Post-reproductive life span and demographic stability. Oikos. 2012;121(9):1370-8. doi: 10.1134/ S0006297913090071.

37. Mitteldorf J, Martins AC. Programmed life span in the context of evolvability. Am Nat. 2014;184(3):289-302. doi: 10.1086 1677387.

38. Mitteldorf J. An epigenetic clock controls ageing. Biogerontology. 2016 Feb;17(1):257-65. doi: 10.1007/s10522-015-9617-5. doi: 10.1007/s10522-015-9617-5.

39. McKevitt TP, Nasir L, Devlin P, Argyle DJ. Telomere lengths in dogs decrease with increasing donor age. J Nutr. 2002; 132(6):1604S-1606S. doi: 10.1093/jn/132.6.1604S.

40. Pauliny A, Wagner RH, Augustin J, Szep T, Blomqvist D. Ageindependent telomere length predicts fitness in two bird species. Mol Ecol. 2006;15(6):1681-7. doi: 10.1111/j.1365294X.2006.02862.x.

41. de Magalhães JP, Curado J, Church GM. Meta-analysis of agerelated gene expression profiles identifies common signatures of ageing. Bioinformatics. 2009;25(7):875-81. doi: 10.1093/ bioinformatics/btp073.

42. Zykovich A, Hubbard A, Flynn JM, Tarnopolsky M, Fraga MF, Kerksick C, Ogborn D, MacNeil L, Mooney SD, Melov S. Genome-wide DNA methylation changes with age in diseasefree human skeletal muscle. Ageing Cell. 2014;13(2):360-6. doi: 10.1111/acel.12180.

43. de Magalhães JP. Programmatic features of ageing originating in development: ageing mechanisms beyond molecular damage? FASEB J. 2012;26(12):4821-6. doi: 10.1096/fj.12-210872.

44. Johnson AA, Akman K, Calimport SR, Wuttke D, Stolzing A, de Magalhães JP. The role of DNA methylation in ageing, rejuvenation, and age-related disease. Rejuvenation Res. 2012; 15(5):483-94. doi: 10.1089/rej.2012.1324.

45. Hayflick L, Moorhead PS. The serial cultivation of human diploid cell strains. Exp Cell Res. 1961;25(3):585-621. doi: 10.1016/0014-4827(61)90192-6.

46. Hayflick L. The limited in vitro lifetime of human diploid cell strains. Exp Cell Res. 1965;37(3):614-36. doi: 10.1016/00144827(65)90211-9.

47. Mitteldorf JJ. How does the body know how old it is? Introducing the epigenetic clock hypothesis. Biochemistry (Mosc). 2013 Sep;78(9):1048-53. doi: 10.1134/S0006297913090113.

48. Tobin DJ. Ageing of the hair follicle pigmentation system. Int J Trichol. 2009 Jul;1(2):83-93. doi: 10.4103/0974-7753.58550.

49. Commo S, Gaillard O, Bernard BA. Human hair graying is linked to a specific depletion of hair follicle melanocytes affecting both the bulb and the outer root sheath. Br J Dermatol. 2004 Mar;150(3):435-43. doi: 10.1046/j.1365-2133.2004.05787.x.
50. Trüeb RM, Tobin D, editors. Ageing Hair. Berlin: Springer, 2010.

51. Ding SL, Shen CY. Model of human ageing: recent findings on Werner's and Hutchinson-Gilford progeria syndromes. Clin Interv Ageing. 2008;3(3):431-44. doi: 10.2147/cia.s1957.

52. Bilgiç Ö. Do you know this syndrome? Werner syndrome. An Bras Dermatol. 2017 Mar-Apr;92(2):271-2. doi: 10.1590/ abd1806-4841.20174640.

53. Praetorius C, Grill C, Stacey SN, Metcalf AM, Gorkin DU, Robinson KC, Van Otterloo E, Kim RS, Bergsteinsdottir K, Ogmundsdottir MH, Magnusdottir E, Mishra PJ, Davis SR, Guo T, Zaidi MR, Helgason AS, Sigurdsson MI, Meltzer PS, Merlino G, Petit V, Larue L, Loftus SK, Adams DR, Sobhiafshar U, Emre NC, Pavan WJ, Cornell R, Smith AG, McCallion AS, Fisher DE, Stefansson K, Sturm RA, Steingrimsson E. A polymorphism in IRF4 affects human pigmentation through a tyrosinase-dependent MITF/TFAP2A pathway. Cell. 2013 Nov 21;155(5):1022-33. doi: 10.1016/j.cell.2013.10.022.

54. Adhikari K, Fontanil T, Cal S, Mendoza-Revilla J, FuentesGuajardo M, et al. A genome-wide association scan in admixed Latin Americans identifies loci influencing facial and scalp hair features. Nature Commun. 2016;7(10815). doi: 10.1038/ ncomms10815.

55. Wood JM, Decker H, Hartmann H, Chavan B, Rokos H, Spencer JD, Hasse S, Thornton MJ, Shalbaf M, Paus R, Schallreuter KU. Senile hair graying: $\mathrm{H} 2 \mathrm{O} 2$ mediated oxidative stress affects human hair color by blunting methionine sulfoxide repair. FASEB J. 2009 Jul;23(7):2065-75. doi: 10.1096/ff.08125435.

56. Seiberg M. Age-induced hair greying - the multiple effects of oxidative stress. Int J Cosmet Sci. 2013 Dec;35(6):532-8. doi: 10.1111/ics.12090. Epub 2013 Oct 10.

57. Trüeb RM. Oxidative stress in ageing of hair. Int J Trichol. 2009 Jan;1(1):6-14. doi: 10.4103/0974-7753.51923.

58. Friedman DB, Johnson TE. Three mutants that extend both mean and maximum life span of the nematode, Caenorbabditis elegans, define the age-1 gene.J Gerontol.1988Jul;43(4):B102-9. doi: 10.1093/geronj/43.4.b102. PMID: 3385139.

59. Johnson TE. Increased life-span of age-1 mutants in Caenorhabditis elegans and lower Gompertz rate of ageing. Science. 1990 Aug 24;249(4971):908-12. doi:10.1126/science.2392681.

60. Khan SS, Shah SJ, Klyachko E, Baldridge AS, Eren M, Place AT, Aviv A, Puterman E, Lloyd-Jones DM, Heiman M, Miyata T, Gupta S, Shapiro AD, Vaughan DE. A null mutation in SERPINE1 protects against biological ageing in humans. Sci Adv. 2017 Nov 15;3(11):eaao1617. doi: 10.1126/sciadvaao 1617. eCollection 2017 Nov.

61. Kenyon C, Chang J, Gensch E, Rudner A, Tabtiang R. A C. elegans mutant that lives twice as long as wild type. Nature. 1993: 366(6454):461-4. doi: 10.1038/366461a0.

62. Dorman JB, Albinder B, Shroyer T, Kenyon C. The age- 1 and daf- 2 genes function in a common pathway to control the lifespan of Caenorhabditis elegans. Genetics. 1995;141:1399-406. PMID: 8601482; PMCID: PMC1206875. 
63. Tatar M, Kopelman A, Epstein D, Tu MP, Yin CM, Garofalo RS. A mutant Drosophila insulin receptor homolog that extends life-span and impairs neuroendocrine function. Science. 2001;292:107-10. doi: 10.1126/science.1057987. PMID: 11292875.

64. Liang H, Masoro EJ, Nelson JF, Strong R, McMahan CA, Richardson A. Genetic mouse models of extended lifespan. Exp Gerontol. 2003;38:1353-64. doi: 10.1016/j.exger.2003. 10.019. PMID: 14698816.

65. Liu X, Jiang N, Hughes B, Bigras E, Shoubridge E, Hekimi S. Evolutionary conservation of the clk-1-dependent mechanism of longevity: loss of mclk1 increases cellular fitness and lifespan in mice. Genes Dev. 2005;19:2424-34. doi: 10.1101/gad. 1352905.
66. Bartke A. Long-lived Klotho mice: new insights into the roles of IGF-1 and insulin in ageing. Trends Endocrinol Metab. 2006;17:33-5. doi: 10.1016/j.tem.2006.01.002.

67. Sonntag WE, Carter CS, Ikeno Y, Ekenstedt K, Carlson CS, Loeser RF, Chakrabarty S, Lee S, Bennett C, Ingram R, Moore T, Ramsey M. Adult-onset growth hormone and insulin-like growth factor I deficiency reduces neoplastic disease, modifies age-related pathology, and increases life span. Endocrinology. 2005;146:2920-32. doi: 10.1210/en.2005-0058.

68. Blagosklonny MV. Ageing and immortality: quasi-programmed senescence and its pharmacologic inhibition. Cell Cycle. 2006;5(18):2087-102. doi: 10.4161/cc.5.18.3288.

Sažetak

\title{
(A)SIMETRIJA MUŠKIH SIJEDIH BRADA KAO INDIKACIJA PROGRAMIRANOG PROCESA STARENJA
}

\author{
B. Poljsak, R. Dahmane, M. Adamič, R. Sotler, T. Levec, D. Pavan Jukić, C. Rotim, T. Jukić i A. Starc
}

Intervencije starenja bit će neučinkovite ako ne razumijemo osnovne principe starenja. Trenutno ne postoji konsenzus o tome je li starenje programirano ili ne. Hipoteza postavljena u ovom članku ukazuje na to da je starenje (barem posijeđivanje muških dlaka) programirano. Tu hipotezu potkrepljuje simetrija posijeđivanja dlaka muške brade. Stohastička teorija starenja tvrdi da je starenje pasivni neprogramirani proces u kojem bi se trebala dogoditi slučajna disperzija sijedih vlasi. Suprotno tome, programirane teorije starenja predviđaju da na lijevom i desnom dijelu lica treba postojati simetrija koja pokazuje jednak omjer, uzorak i vrijeme pojave sijedih dlačica.

Ključne riječi: Sijeda dlaka na bradi; Sijede vlasi; Starenje; Programirana teorija starenja; Stohastička teorija starenja 